\title{
January Temperatures Predict Tobacco Blue Mold Severity: Evidence for Local Source and Long-Distance Transport of Inoculum in Connecticut
}

\author{
J. A. LaMondia, The Connecticut Agricultural Experiment Station Valley Laboratory, Windsor, CT 06095
}

\begin{abstract}
LaMondia, J. A. 2010. January temperatures predict tobacco blue mold severity: Evidence for local source and long-distance transport of inoculum in Connecticut. Plant Dis. 94:119-124.

The tobacco blue mold pathogen, Peronospora tabacina, has been periodically reintroduced to the Connecticut River Valley cigar wrapper tobacco (Nicotiana tabacum) area of Connecticut and Massachusetts. Once introduced, there is a greater likelihood of disease in following years. Blue mold occurred from 1937 to 1956, 1979 to 1981, and most recently from 1996 to 2008. Disease severity was evaluated and rated annually from 1979 to 2008, and was correlated $(r=$ $0.84 ; P=0.002$ ) with January temperatures when the pathogen was present in moderate amounts the previous year (severity rating $>1$ ). The date of the first report of disease was negatively correlated with disease severity the previous year $(r=-0.63)$ and February temperatures $(r=-0.83)$. Blue mold severity was not correlated with the date of the first disease, the previous year's disease severity, or rainfall amount or frequency after introduction of the pathogen. January temperatures may be used to predict the need for early-season fungicide applications to control disease from local overwintering inoculum following moderate to high blue mold severity. In years following little or no disease, forecasts of long-distance transport will continue to be a valuable tool to predict the risk of long-distance reintroduction and the need for fungicide application based on exposure.
\end{abstract}

Tobacco blue mold, caused by the oomycete pathogen Peronospora tabacina Adam (Peronospora hyoscyami de Bary), is an economically important leaf spot disease of the cigar wrapper tobacco types (Nicotiana tabacum L.) grown in the Connecticut River Valley of Connecticut and Massachusetts. The pathogen infects a wide range of Nicotiana species and has been a major problem affecting cultivated tobacco in the United States for many years.

Blue mold was first reported on cultivated tobacco on the North American continent in 1921, when it was found in Florida and Georgia (30,31). It showed up again in the same region in 1931, spreading to North Carolina, Virginia, Maryland, and Louisiana. In 1932, it had spread as far north as Lancaster County, PA. It continued to occur in the same locations each year and spread to new locations such as Tennessee and Kentucky in subsequent

Corresponding author: J. A. LaMondia E-mail: James.LaMondia@ct.gov

* The $e$-Xtra logo stands for "electronic extra" and indicates that Figure 1 appears in color in the online edition.

Accepted for publication 3 September 2009.

doi:10.1094/PDIS-94-1-0119

(C) 2010 The American Phytopathological Society years. Blue mold first occurred in Connecticut in 1937 (1), and occurred annually in Connecticut from 1937 to 1956. It was primarily a disease of tobacco in seedbeds, although some disease occurred in the field and in shade tents each year from 1942 to 1950 , especially in cool, wet years (2). During these years, blue mold occurred mainly early in the season, and was apparently restricted from affecting plants under field conditions by high summer temperatures (26). Control tactics developed to combat blue mold consisted of sanitation, fungicide protection of seedlings in beds, and the reduction of potential overwintering inoculum (2). After 1956, there were no reports of blue mold in the Connecticut River Valley until 1979. The lack of disease prior to 1979 was no doubt due to good disease control in Connecticut and elsewhere, and the inability of the pathogen to consistently infect tobacco in the field during hot or dry conditions.

Prior to 1979 , it was stated in the literature that primary infection was the result of local oospore germination and infection of tissue in contact with soil in tobacco transplant beds. Clayton and McMurtry (8) stated that "The infection can live over in old bed soil". Valleau et al. (33) wrote "The fungus overwinters in the Georgia Florida area on volunteer tobacco and probably as oospores in old beds, and farther north in plant beds used the previous year. The disease usually appears about 2 weeks earlier in old beds than in new ones. It produces heavy-walled resting spores in the dying or dead leaves. These are capable of remaining in the soil at least a year and attacking the next crop of plants if the same site is used again for tobacco plants." In Connecticut, "a second type of spore, the winter spore, is produced buried in the interior of the affected leaf in contact with the soil. They do not germinate at once when mature, but after the leaf has decayed, remain in the soil and germinate at the right time to start infection in the young beds. These oospores have been found rather frequently in the southern states. The writer has found them in Connecticut and no doubt they occur here commonly" (1). Anderson and Swanback (3) also stated that mildew first appeared in Connecticut about 15 May, but during early springs it may attack plants in beds earlier in the month. This was typically 1 or 2 weeks before the earliest field planting date. Successful management was targeted at disease carryover in transplant beds (8). Oospore formation ranged from extensive to below detectable levels, perhaps based on unknown environmental triggers. Wolf et al. (36) demonstrated that oospores could survive for up to 4 years, while Person et al. (25) could not initiate oospore germination, perhaps due to biological predation. Other researchers demonstrated oospore infectivity at low levels for up to 50 months in natural soils $(15,16)$. Oospore morphology was also shown to differ with different isolates of the pathogen (32).

Blue mold episodes since 1979 have been assumed to be associated with longdistance transport of sporangia, and the role of oospores in primary infection has been de-emphasized (10). The exception was Aylor et al. (6), who stated that the 1981 occurrence in Connecticut was almost certainly due to overwintering. In 1979, an isolate of P. tabacina capable of causing disease during warm (hot) weather in the field resulted in a blue mold pandemic in the U.S. tobacco crop that caused losses of more than $\$ 250$ million (18). The disease caused a $20 \%$ yield loss in Connecticut even though $60 \%$ of the crop had already been harvested by the time the pathogen was first observed (6).

In 1979, blue mold was likely introduced to Connecticut by long-distance 
aerial transport of sporangia from large areas of heavily diseased tobacco located hundreds of kilometers away (6). While blue mold may be periodically reintroduced into distant regions by long-distance transport, this, like infection by oospores, is also a relatively unlikely event. Longdistance transport and infection requires high levels of inoculum at a source, conditions conducive for sporangia release, wind transport in the direction of the target, transport during cloudy conditions to reduce mortality due to UV radiation, and rainfall to wash sporangia from air and aid in infection in the distant target crop (5).

While there is evidence that the blue mold pathogen may have been periodically reintroduced into Connecticut via longdistance aerial transport of sporangia, there is also strong circumstantial evidence for the occasional survival over winter under field or greenhouse conditions. There are a number of different means of initiating epiphytotics, and it is reasonable to expect that different mechanisms may be responsible for it in different years. Some of the possible mechanisms include long-distance transport of airborne sporangia, longdistance transport of infected plants by people, overwintering of infected plants in protected locations, and overwinter survival of oospores. Collecting and identifying isolates by techniques such as polymerase chain reaction (PCR) would aid in the study of long-distance movement and local survival (27).

Sporangia of $P$. tabacina can be aerially dispersed over long distances and likely initiate new outbreaks of blue mold, but the evidence for long-distant transport and infection is largely circumstantial $(4,6)$. For successful long-distant transport to occur, conditions conducive for sporulation at a strong source must be followed by air movement from the source directed to the target crop. Sporulation of P. tabacina requires at least $95 \%$ relative humidity for a minimum of $3 \mathrm{~h}$ during a dark period of greater than $1.5 \mathrm{~h}(9)$, whereas maximum sporulation occurs at 97 to $100 \%$ relative humidity. Conditions for transport must be conducive for survival of sporangia for between 20 and $30 \mathrm{~h}$, the approximate length of time required for sporangia to be transported 500 to $700 \mathrm{~km}$ in the atmosphere. In addition, there should be little or no rain washout of sporangia along the trajectory until the target area is reached, at which point rain is needed both for deposition of sporangia on the crop and for conditions suitable for infection (6). Sporangia of $P$. tabacina are subject to mortality by solar radiation. Only 3\% of detached sporangia survived a 3-h exposure (28). As a result, there may be comparable or more danger to a tobacco field from a very small, potentially unnoticed, local source than from a massive source $700 \mathrm{~km}$ away (6).

The U.S. Department of Agriculture established a blue mold warning system in
1945 to relay information on risk of blue mold activity to all tobacco production areas. This service, discontinued prior to the epiphytotic in 1979, was reinstituted during that year (24). Currently, a World Wide Web based North American blue mold forecast system at North Carolina State University predicts the likelihood of blue mold exposure due to local and longdistance transport (23). Atmospheric transport of sporangia is calculated using the HY-SPLIT trajectory model (11), and trajectories are obtained and calculated from the U.S. National Oceanic and Atmospheric Administration, Air Resources Laboratory.

The availability of local and long-range forecasts of blue mold exposure has been useful for farmers growing tobacco types that can tolerate significant levels of blue mold without incurring large economic losses. In the Connecticut River Valley, where the high value of the crop makes even limited infection very costly, longdistance forecasts may be most useful for determining the risk of exposure to blue mold. Growers can avoid early-season fungicide sprays in years when blue mold is not present in growing regions to the south or where disease was not present in the Connecticut Valley the previous year. Once the pathogen is present in any year, the utility of local forecasts is low because the level of disease that can be tolerated without economic loss is extremely low in cigar wrapper tobaccos. A single leaf lesion may result in a loss of $75 \%$ of the marketable wrapper leaf value. Sporangia can be transported by wind the length of the Connecticut River Valley production area $(100 \mathrm{~km})$ in only about half the time required to kill all of the sporangia under sunny, dry conditions. The current lack of a systemic fungicide with curative activity does not allow growers the luxury to postpone sprays and still control the disease.

While movement of infected transplants has not been suspected as a means of direct introduction of the pathogen to Connecticut and Massachusetts (in part because a unique type is grown there), it has been responsible for long-distance transport elsewhere (24). It is possible to move the disease around unknowingly on infected, asymptomatic plants. Plants can have latent infections without symptoms for 5 to 10 days after infection, and transplants may be set in the field before symptoms appear. A PCR assay may be used to detect the pathogen in asymptomatic transplants (23). Movement of the pathogen in transplants appears to have happened in Kentucky in 1996 (14) and in Pennsylvania in 1997 (19). Transplants have brought the disease to locations close enough to Connecticut, such as Pennsylvania, to be a source of sporangia to initiate an epiphytotic here.

$N$. tabacum is not the only plant infected by the pathogen, nor is it the only plant capable of transporting the disease with movement of plants (17). Both wild tobacco species and ornamental tobacco types can be infected by the pathogen. $N$. repanda Willd. ex Lehm. has been associated with blue mold in the American Southwest and may act as a source of annual infection (29). Other Nicotiana spp., such as $N$. alata Link \& Otto, $N$. sanderae Hort. ex Watson $(N$. alata $\times N$. forgetiana Hort. ex Hemsley), and $N$. sylvestris Speg. are widely grown as ornamentals in the Northeastern United States and elsewhere. The movement of infected ornamental plants to the Connecticut River Valley from an infested area, or the local overwinter survival of the pathogen in systemically infected ornamentals under greenhouse conditions, has been a major concern to tobacco growers. It is thought that Nicotiana species grown over the winter in a greenhouse were either the first to be infected by distant or unknown local sources, or they may have overwintered the pathogen and initiated the disease in 2000 in Massachusetts.

Episodes of potential overwintering of the pathogen in the Connecticut River Valley may also be associated with survival and infection by oospores, as was assumed to be the primary cause of infection prior to 1979 . Oospores have been found in Connecticut following years with widespread blue mold infection. In 1997, cured shade and broadleaf leaves with blue mold lesions were collected from 15 locations in Connecticut and Massachusetts (17). At least six leaf disks per sample location were cut from symptomatic lesions with a 1-cm-diameter cork borer and cleared in boiling $5 \% \mathrm{KOH}$ for $20 \mathrm{~min}$. Half of the leaf disks were stained with cotton blue in lacto-phenol, and all disks were examined under a compound microscope. Of the 100 disks examined, 14 had structures similar to the oospores described by Spurr and Todd (32). Hyphae, haustoria, sporangia, and sporangiophores were also present in the cleared tissue. Oospores observed in 1997 were spherical, with an echinulate wall of approximately $5-\mu \mathrm{m}$ thickness, and ranged in diameter from 25 to $35 \mu \mathrm{m}$ (Fig. 1). Oospores were present singly or in small clusters of up to 11 per leaf disk in the leaf mesophyll (17).

$P$. tabacina could survive as vegetative hyphae in roots of systemically infected plants, and that root transmission could occur in both wild and commercial Nicotiana species (12). This may have a significant impact on survival of $P$. tabacina over winter in protected beds, under debris in fields, or under greenhouse conditions. It would also help to explain circumstantial evidence for overwinter survival despite low oospore infectivity, as germinating oospores may infect tobacco roots as well as foliage. We may never understand the complete role of oospores in the epidemiology of blue mold because of several 
factors, including the obligate nature and economic impact of the pathogen, differences in oospore production among isolates, uncertainty about whether mating types exist, and the low infectivity of the oospores. The low incidence, poor germination, and low infectivity of oospores are often cited to dismiss the importance of oospores on epidemiology $(15,32)$. However, the greater the distance that a tobacco-producing area is from the source of windborne sporangia, the greater the potential importance of any infection due to oospores overwintering from a previous year's epidemic and the more difficult it is to discount them.

One of the earliest successful plant disease forecasting models developed used January temperatures to predict the severity of tobacco blue mold $(21,22)$. Severe disease corresponded with warmer than normal January temperatures in locations from Florida to Virginia. It was assumed that warm January temperatures increased oospore survival or germination and infection (22).

We have associated potential overwinter episodes (or disease present prior to likely long-distance transport) with medium to heavy but not low to medium disease severity in the previous year (Table 1). Disease severity ratings were determined annually as an overall assessment of blue mold losses in the Connecticut River Valley based on diagnostic samples submitted, visits to farms, interviews with growers, and claims for insurance losses.

We postulated in 2001 (17) that Connecticut (lat. $41^{\circ} 45^{\prime} \mathrm{N}$, long. $72^{\circ} 40^{\prime} \mathrm{W}$ ), one of the more distant locations north of the typical initial sources of blue mold infection in the United States, offers an excellent opportunity to study a periodically introduced disease such as blue mold. Tobacco is grown on a relatively small acreage in the Connecticut River Valley in Connecticut and Massachusetts, and isolated from the nearest large-scale tobacco production area by about $400 \mathrm{~km}$. It seems likely that $P$. tabacina may have been introduced by long-distance transport into the Connecticut River Valley in some of the years during 1979 to 1980 and 1996 to 2008. There is also reason to believe that in other years the pathogen was present prior to exposure from long-distance transport from distant sources. The environmental conditions in shade tents are very conducive for disease so that disease severity in shade tobacco can be high over a wide range of weather conditions (34). The estimated severity of disease each year, severity the previous year, and the likely source of infection are presented in Table 1. A short history of the disease in the Connecticut River Valley over this time follows to support the table.

Before 1979, the disease had been absent from Connecticut for 22 years. After the blue mold pandemic of 1979 , the dis- ease occurred again in Connecticut in 1980. Losses in 1980 were reduced due to the increasing use of metalaxyl, a highly effective systemic fungicide. In 1981, blue mold was effectively controlled by metalaxyl and few cases were reported anywhere in the United States. Despite the near absence of blue mold in other production areas, the disease was discovered in a small $(15 \times 15 \mathrm{~m})$ area of 0.1 -m-tall volunteer shade tobacco seedlings growing among weeds and diseased tobacco trash in Windsor, CT (6). The geographic isolation of these plants combined with the extremely small inoculum production by the few scattered locations of diseased plants at distant sources elsewhere in the United States strongly suggests that the pathogen overwintered in 1980-81 in several areas, including Windsor (24).

Widespread use of metalaxyl essentially eliminated blue mold from the Connecticut
River Valley and much of the United States until the early 1990s. Metalaxyl-resistant strains of P. tabacina were first reported in 1981 and 1982 in Nicaragua (13). Resistant strains were subsequently reported in Mexico in 1984 and in the United States in 1991 (35). Despite disease in flue-cured and burley tobaccos in southern production areas, blue mold was not identified in the Connecticut River Valley again until 1996, when metalaxyl-resistant isolates of $P$. tabacina were discovered in October in tobacco breeding lines left in the field for seed production.

Blue mold reoccurred in Connecticut in July 1997 and has been present each year until the present (2008). Transplants with latent blue mold infection were brought to Pennsylvania from a southern source early in the 1997 season, and airborne sporangia from Pennsylvania were thought to have initiated the Connecticut epiphytotic,

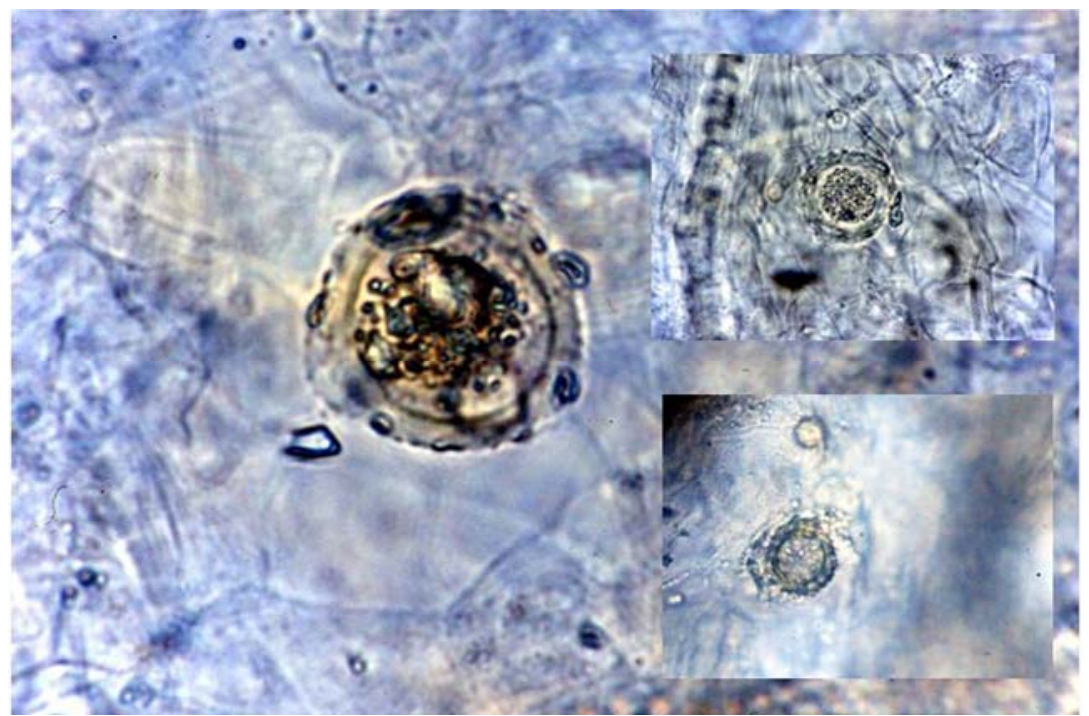

Fig. 1. Oospores observed in leaves of blue mold-infected tobacco in Connecticut and Massachusetts, 1998.

Table 1. Association of blue mold severity in the present and previous year in the Connecticut River Valley and the likely source of initial inoculum (local overwintering versus long-distance dispersal) of Peronospora tabacina

\begin{tabular}{llllcl}
\hline Year & \multicolumn{1}{c}{ Disease severity } & $\left(\right.$ rating $\left.^{\mathbf{a}}\right)$ & Previous severity & First occurrence & Source \\
\hline 1979 & Heavy & $(5)$ & None & 30 July & Long distance \\
1980 & Medium & $(3)$ & Heavy & 13 July & Long distance \\
1981 & Negligible & $(0)$ & Medium & 23 June & Overwinter \\
1997 & Heavy & $(5)$ & Low & 8 July & Long distance \\
1998 & Heavy & $(5)$ & Heavy & 14 June & Overwinter \\
1999 & Medium & $(3)$ & Heavy & 28 June & Overwinter \\
2000 & Low-medium & $(2)$ & Medium & 23 June & Overwinter \\
2001 & Locally heavy & $(4)$ & Low-medium & 23 July & Long distance \\
2002 & Locally heavy & $(4)$ & Locally heavy & 26 June & Overwinter \\
2003 & Low-medium & $(2)$ & Locally heavy & 10 July & Overwinter \\
2004 & Low & $(1)$ & Low-medium & 3 August & Long distance \\
2005 & Low & $(1)$ & Low & 15 July & Long distance \\
2006 & Low & $(1)$ & Low & 17 July & Long distance \\
2007 & Low & $(1)$ & Low & 31 July & Long distance \\
2008 & Negligible & $(0)$ & Low & October & Long distance \\
\hline
\end{tabular}

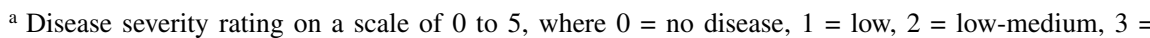
medium, $4=$ medium-high, and $5=$ high.

${ }^{b}$ A small amount of blue mold occurred in experimental plots at the CAES Research Farm, but no disease was reported from commercial production. 
which was first reported on 8 July in Windsor. Disease caused significant economic losses from 1997 to 1999 (severity ratings of 5,5 , and 3 , respectively). The first confirmed reports of blue mold in the Connecticut River Valley in 1998 and 1999 were from transplant production: hoophouse seedling production in Hadley, MA in June 1998, and from plant beds in northern Connecticut in June 1999. In both years, blue mold was confirmed prior to the time of high-risk exposure from longdistance sporangia transport (North American Blue Mold Warning System).

While there was the possibility of some early-season exposures from extremely long-distance sources in North Carolina in 2000, blue mold was first confirmed in the Connecticut River Valley on a small collection of ornamental tobacco plants in a greenhouse at the University of Massachusetts in June 2000. Low to medium levels of disease were present in the Connecticut River Valley in 2000. In 2001, the first report of blue mold was from Hadley, MA on 23 July. Substantial losses occurred locally. The disease occurred after longdistance exposure was reported and was likely the result of long-distance transport.

There is another line of evidence in support of long-distance dispersal to Connecticut in 2001. The isolate of the pathogen present was different from the previous 3 years. Evidence comes from observations of tobacco disease resistance in our tobacco breeding program. In 1998, we tested Clayton's breeding lines 292-393 and 509 obtained from the Oxford, NC Seed Storage Laboratory, found them to be to be highly resistant to blue mold, and used them in the Connecticut resistancebreeding program (7). Our results indicated that 292-393 was virtually immune to blue mold, and that line 509 exhibited a reduced level of resistance. One blue mold-resistant F1 hybrid that we created using 509 as a male parent, CT-110, had promising leaf quality characteristics and significant levels of resistance. Although resistance was not complete in the F1, CT$110 \mathrm{~F} 1$ had significantly fewer and smaller lesions, and allowed less sporulation than susceptible tobacco lines. This resistance was stable in 1999 and 2000, but in 2001 line CT-110 F1 was found to be susceptible to the disease, indicating that variation in the pathogen existed and the isolate present in 2001 was able to cause significant disease despite the resistance genes. Based on this evidence, we concluded that the new or at least different isolate of the pathogen very likely had been introduced to Connecticut from a distant source.

In 2002, the first report of blue mold was from shade tobacco in Windsor on 26 June. John Yocum of Pennsylvania State University (personal communication) reported that strong sources of blue mold in that state did not occur until after 26 to 28 June. Because it takes at least one and usually more than one 5- to 7-day latent period cycle to discover the disease in the field, there was strong circumstantial evidence of overwintering. Once again, CT110 was susceptible to blue mold. Locally heavy losses occurred. Blue mold occurred again on 10 July 2003 in shade tobacco in Suffield, CT, again prior to long-distance exposure from southern sources. While the disease was not widespread within the field, there were two generations of lesions, indicating that first infection likely occurred late in June. Low to medium levels of disease resulted. From 2004 to 2008, disease levels were low, and the pathogen was likely reintroduced each year by long-distance transport as disease occurred after exposure predicted by the North Carolina Plant Disease Forecast Center.

By examining the repeated episodes of evidence of disease prior to reported high risk exposure from long-distance sources in the Connecticut River Valley over a number of years from 1979 to 1982 and 1997 to 2008 , we were able to test the relationship between mean January temperatures and disease severity, i.e., the same factor that was used to forecast disease in the 1930s and 1940s (21). Disease severity in the Connecticut River Valley was rated annually on a scale of 0 to 5 , where 0 represented no disease and 5 represented severe losses. Average January temperatures from Windsor Locks, CT were correlated (Spearman rank correlation test) with disease severity, and regression analyses were performed. Similarly, December and February temperatures, winter mean temperatures (mean of December, January, and February), amount of rain and number of days with precipitation from 1 week prior to the first observed disease through the end of August, and the date of the first occurrence of blue mold reported in Connecticut or Massachusetts were also tested for correlation with disease severity.

Our initial results for all years indicated that mean January temperature was poorly correlated with disease severity $(r=0.27$; $P=0.32$ ) (Table 2). However, January temperature would have little impact on overwintering if the pathogen was not present or present in sufficient numbers to cause moderate disease the previous year, and when we filtered the data for the presence of the pathogen and significant disease in Connecticut or Massachusetts the previous year (years with disease severity $>1$ [low]), the relationship between January temperature and blue mold severity was very significant $(r=0.84 ; P=0.002)$. Blue mold severity was regressed against mean January temperature for all years with blue mold from 1979 to 2008 and only for years when $P$. tabacina was present in the valley and caused disease severity $>1$ the previous year (Fig. 2). A significant linear relationship was observed for the latter [Disease severity $=0.42$ (January temperature) $\left.+4.54 ; R^{2}=0.71, P=0.002\right]$. Mean February or previous December temperatures or mean winter temperatures (the average of December through February) were not correlated with disease severity. Other factors such as the date of first blue mold occurrence, disease severity the previous year, and the amount of rain and number of days with precipitation from 1 week prior to the first observed disease through the end of August were not correlated with disease severity. The first

Table 2. Correlation coefficients between regional ratings of blue mold disease severity in the Connecticut River Valley from 1979 to 2008 and winter temperatures $^{\mathrm{a}}$

\begin{tabular}{|c|c|c|c|c|c|c|c|c|c|c|}
\hline Factors & $\begin{array}{l}\text { Disease } \\
\text { all years }\end{array}$ & $\begin{array}{c}\text { Disease } \\
(\text { prev }>1)\end{array}$ & $\begin{array}{l}\text { January } \\
\text { mean C }\end{array}$ & $\begin{array}{l}\text { December } \\
\text { mean C }\end{array}$ & $\begin{array}{c}\text { February } \\
\text { mean } \mathrm{C}\end{array}$ & $\begin{array}{l}\text { Winter } \\
\text { mean C }\end{array}$ & $\begin{array}{c}\text { First } \\
\text { disease }\end{array}$ & $\begin{array}{l}\text { Previous } \\
\text { disease }\end{array}$ & $\begin{array}{l}\text { Rain } \\
(\mathbf{c m})^{\mathbf{b}}\end{array}$ & $\begin{array}{c}\text { Rain } \\
(\text { days })^{\mathrm{b}}\end{array}$ \\
\hline Disease severity (all years) & 1.00 & & & & & & & & & \\
\hline $\begin{array}{l}\text { Disease severity (previous } \\
\text { year severity rating }>1 \text { ) }\end{array}$ & 1.00 & 1.00 & & & & & & & & \\
\hline January mean temperature & 0.27 & $0.84 * \mathrm{c}$ & 1.00 & & & & & & & \\
\hline December mean temperature & 0.28 & 0.12 & 0.37 & 1.00 & & & & & & \\
\hline February mean temperature & 0.19 & 0.05 & 0.12 & 0.06 & 1.00 & & & & & \\
\hline Winter mean temperature & 0.28 & 0.37 & $0.74 *$ & $0.63 *$ & $0.58 *$ & 1.00 & & & & \\
\hline Date first disease reported & -0.30 & -0.04 & -0.07 & -0.05 & $-0.83 *$ & -0.40 & 1.00 & & & \\
\hline Previous disease severity & 0.26 & 0.10 & -0.03 & 0.19 & 0.38 & 0.23 & $-0.63 *$ & 1.00 & & \\
\hline Rainfall amount $(\mathrm{cm})^{\mathrm{b}}$ & -0.07 & -0.15 & -0.19 & -0.48 & 0.04 & -0.24 & -0.22 & 0.19 & 1.00 & \\
\hline Rainfall frequency $(\text { days })^{b}$ & 0.32 & 0.15 & 0.02 & -0.21 & 0.22 & 0.02 & -0.36 & 0.18 & $0.67 *$ & 1.00 \\
\hline
\end{tabular}

${ }^{a}$ Correlations are shown for all years with disease and for those years for which moderate disease (severity rating $>1$ ) occurred locally the previous year.

${ }^{\mathrm{b}}$ Rainfall amount and frequency: seasonal total from 1 week prior to first occurrence of disease through end of August.

${ }^{c}$ Spearman rank correlation coefficients followed by an asterisk are significant at $P=0.05$ or greater. 
date of disease reported was negatively correlated with the severity of disease the previous year, indicating that disease occurred earlier when disease severity was high the year before, also consistent with the hypothesis that the pathogen overwintered in certain years when disease pres-

It is intriguing that the same model that was proposed to predict the severity of blue mold in plant beds based on overwinter survival of the pathogen was found to be significant for recent blue mold episodes following years when the pathogen was well established in the Connecticut River Valley. This suggests that the same mechanism(s) may be active for the warmweather-tolerant isolates of the pathogen sure was significant.

as for the isolates present decades ago, and is further circumstantial evidence that the blue mold pathogen may overwinter locally in certain years.

The spread of blue mold by longdistance aerial dispersal of sporangia in the atmosphere is generally a low probability event, but it can happen when disease pressure is high, the source is nearby (within $500 \mathrm{~km}$ ), and weather conditions are conducive for infection (6). The fact that blue mold was absent from Connecticut for long stretches of time (between 1957 and 1979 and between 1981 and 1996) is an indication that long-distance transport of sporangia to Connecticut is an unlikely event, as there was at least some disease in southern tobacco production areas in many
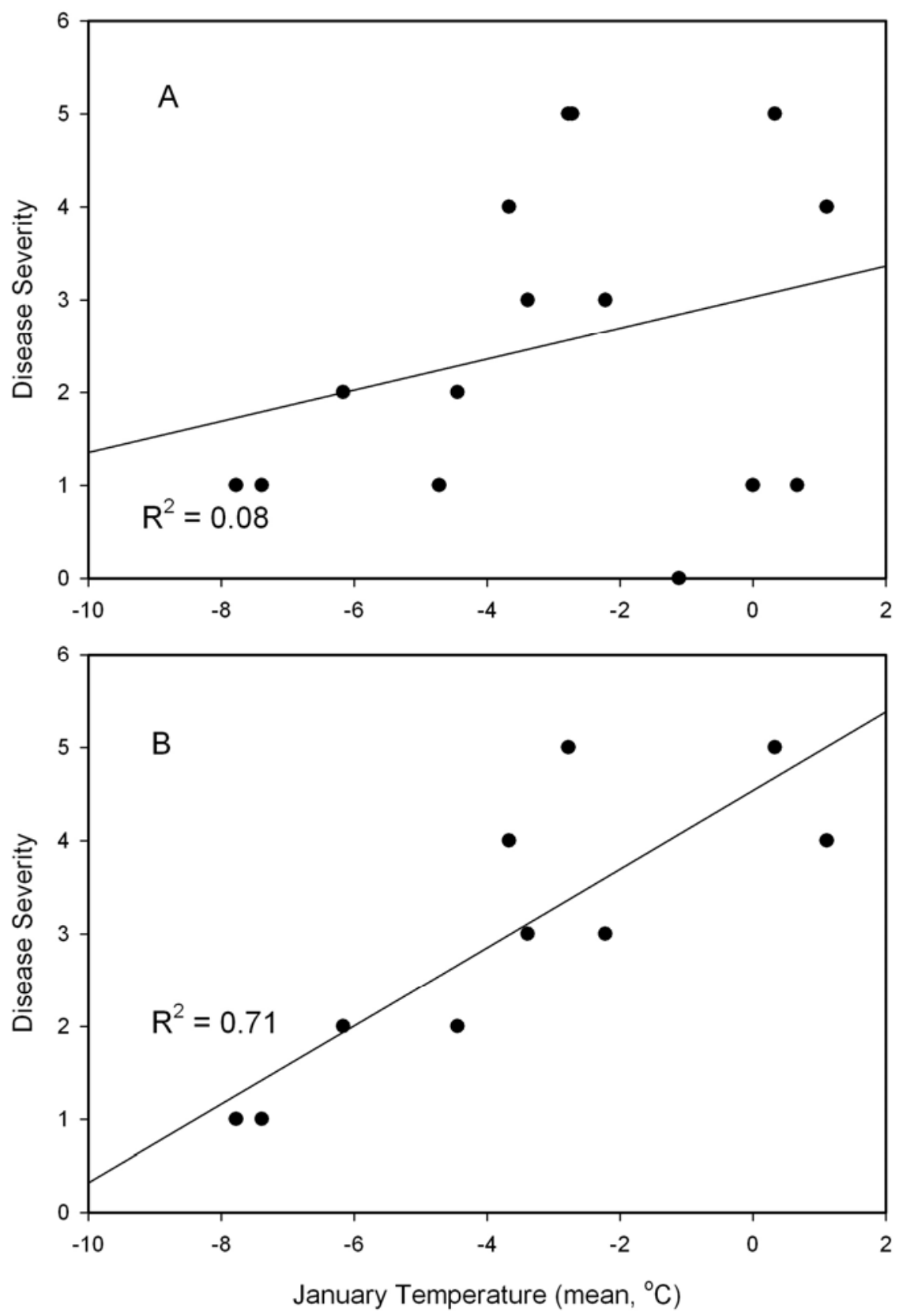

Fig. 2. Blue mold severity in the Connecticut River Valley as a function of mean January temperature A, for all years with blue mold from 1979 to 2008 and B, for only those years when Peronospora tabacina caused moderate disease in the valley during the previous year. of those years. Movement of transplants may not play the same role as in other areas, as the tobacco types grown here are unique and usually produced locally. Overwintering is also a low probability event; however, because of the history of back-to-back episodes of disease in Connecticut, growers are at greater risk of blue mold following a year with abundant disease in the field. This may be due to longdistance transport from a close source such as Pennsylvania or to an overwintering local source. We have strong circumstantial evidence that both may occur. Oospores have been found in infected leaves, historically and recently, and evidence for overwintering is supported by the fact that mean January temperatures may be used to predict the severity of disease from assumed local sources when disease severity was moderate the previous year. Oospore survival in soil and plant infection the next year is undoubtedly a very unlikely event, and it is not surprising that attempts to demonstrate this with small plots or controlled experiments have been negative. However, in certain years there may be more or comparable danger to cigar wrapper tobacco in Connecticut and Massachusetts from a very small, potentially unnoticed, local source than from a massive source hundreds of kilometers away (6). The analysis presented here suggests that following years with moderate to high blue mold severity, it may be possible for growers to use January temperatures to predict the need for early-season fungicide applications to control potential infections from local overwintering sources of inoculum. In years following no disease or low disease severity, early-season fungicide applications may be unnecessary. Forecasts of long-distance transport will continue to be a valuable tool to predict the risk of longdistance reintroduction and the need for fungicide application based on exposure.

\section{ACKNOWLEDGMENTS}

I thank D. E. Aylor for thoughtful review and comments, and C. E. Main, A. Mila, and T. Keever of the North American Plant Disease Forecast Center at NCSU for providing accurate and timely season-long blue mold forecasts.

\section{LITERATURE CITED}

1. Anderson, P. J. 1937. Downy mildew of tobacco. Connecticut Agricultural Experiment Stn. Bull. 405.

2. Anderson, P. J. 1952. Combating blue mold of tobacco. Connecticut Agricultural Experiment Stn. Circ. 181.

3. Anderson, P. J., and Swanback, T. R. 1950. Tobacco seedbeds. Connecticut Agricultural Experiment Stn. Circ. 175.

4. Aylor, D. E. 1986. A framework for examining inter-regional aerial transport of fungal spores. Agric. For. Meteorol. 38:263-288.

5. Aylor, D. E. 1999. Biophysical scaling and the passive dispersal of fungus spores: Relationship to integrated pest management strategies. Agric. For. Meteorol. 97:275-292.

6. Aylor, D. E., Taylor, G. S., and Raynor, G. S. 1982. Long-range transport of tobacco blue mold spores. Agric. Meteorol. 27:217-232. 
7. Clayton, E. E. 1968. The transfer of blue mould resistance to tobacco from Nicotiana debneyi. Part IV - breeding programs 19571967. Tob. Sci. 12:112-124.

8. Clayton, E. E., and McMurtry, J. E., Jr. 1985. Tobacco diseases and their control. U.S. Dep. Agric. Farmers Bull. No. 2023.

9. Cruickshank, I. A. M. 1958. Environment and sporulation in phytopathogenic fungi. I. Moisture in relation to the production and discharge of conidia of Peronospora tabacina Adam. Aust. J. Biol. Sci. 11:162-170.

10. Davis, J. M., and Main, C. E. 1984. A regional-analysis of the meteorological aspects of the spread and development of blue mold on tobacco. Boundary-layer Meteorol. 28:271304.

11. Draxler, R. R. 1992. Hybrid single-particle Lagrangian integrated trajectories (HY-SPLIT): Version 3.0 - User's Guide and Model Description. NOAA Technical Memo. ERLARL-195.

12. Heist, E. P., Nesmith, W. C., and Schardl, C. L. 2000. Interactions of the tobacco downy mildew pathogen, Peronospora tabacina, with host roots. (Abstr.) Phytopathology 90:S126.

13. Johnson, G. I. 1989. Peronsospora hyoscyami de Bary: Taxonomic history, strains, and host range. Pages 1-18 in: Blue Mold of Tobacco. American Phytopathological Society, St. Paul, $\mathrm{MN}$.

14. Keever, T. 1996. Meteorological Aspects and Forecast Chronology of the 1996 Blue Mold Epidemic. http://www.ces.ncsu.edu/depts/pp/ bluemold/history/1996/96retrpt.htm

15. Krober, H. 1969. Uber das Infektionsverhalten der Oosporen von Peronospora tabacina Adam an tabak. Phytopathol. Z. 64:1-6.

16. Krober, H., and Weinmann, W. 1964. A contribution to the morphology and taxonomy of Per- onospora tabacina. Phytopathol. Z. 51:241-251.

17. LaMondia, J. A., and Aylor, D. E. 2001. Epidemiology and management of a periodically introduced pathogen. Biol. Invasions 3:273282.

18. Lucas, G. B. 1980. The war against blue mold. Science 210:147-153

19. Main, C. E., and Keever, T. 1997. Spread and development of the 1997 blue mold epidemic in North America. http://www.ces.ncsu.edu/ depts/pp/bluemold/history/1997/metsum97. htm

20. Melton, T. A., Davis, J. M., Barnett, O. W., Shoemaker, P. B., Creswell, T., Corl, J. D., and Kincy, K. 2000. North American Plant Disease Forecast Center Homepage. http://www.ces. ncsu.edu/depts/pp/bluemold/

21. Miller, P. R. 1959. Plant disease forecasting. Pages 557-565 in: Plant Pathology Problems and Progress 1908-1958. University of Wisconsin, Madison.

22. Miller, P. R., and O'Brien, M. 1949. January temperatures in relation to the distribution and severity of downy mildew of tobacco II. A review of the past nineteen years. Plant Dis. Rep. 33:418-425.

23. Mina, A., and Keever, T. 2009. Tobacco blue mold forecast. www.ces.ncsu.edu/depts/pp/blue mold

24. Nesmith, W. C. 1984. The North American blue mold warning system. Plant Dis. 68:933936.

25. Person, L. H., Lucas, G. B., and Koch, W. G. 1955. A chytrid attacking oospores of Peronospora tabacina. Plant Dis. Rep. 39:887-888.

26. Rider, N. E., Cruickshank, I. A. M., and Bradley, E. F. 1961. Environment and sporulation of phytopathogenic fungi. III. Peronospora tabacina Adam: Field environment, sporulation and forecasting. Aust. J. Agric.
Res. 12:1119-1125.

27. Ristaino, J. B., Johnson, A., Blanco-Meneses, M., and Liu, B. 2007. Identification of the tobacco blue mold pathogen, Peronospora tabacina, by polymerase chain reaction. Plant Dis. 91:685-691.

28. Rotem, J., Wooding, B., and Aylor, D. E. 1985. The role of solar radiation, especially ultraviolet, in the mortality of fungal spores. Phytopathology 75:510-514.

29. Reuveni, M., Nesmith, W. C., Siegel, M. R., and Keeny, T. M. 1988. Virulence of an endemic isolate of Peronospora tabacina from Texas to Nicotiana tabacum and $N$. repanda. Plant Dis. 72:1024-1027.

30. Schiltz, P. 1981. Downy mildew of tobacco. Pages 577-599 in: The Downy Mildews. D. M Spencer, ed. Academic Press, New York.

31. Smith, E. F., and McKenny, R. E. B. 1921. A dangerous tobacco disease appears in the United States. U.S. Dep. Agric. Circ. 174.

32. Spurr, H. W., Jr., and Todd, F. A. 1982. Oospores in blue mold diseased North Carolina burley and flue-cured tobacco. Tob. Sci. 26:4446.

33. Valleau, W. D., Johnson, E. M., and Diachun, S. 1954. Tobacco diseases. University of Kentucky College of Agriculture and Home Economics Circ. 522.

34. Waggoner, P. E., Pack, A. B., and Reifsnyder, W. E. 1959. The climate of shade. Connecticut Agricultural Experiment Stn. Bull. 626.

35. Wiglesworth, M. D., Reuveni, M., Nesmith, W. C., Siegel, M. R., Kuc, J., and Juarez, J. 1988. Resistance of Peronospora tabacina to metalaxyl in Texas and Mexico. Plant Dis. 72:964-967.

36. Wolf, F. A., McLean, R. A., and Dixon, L. F 1936. Further studies on downy mildew of tobacco. Phytopathology 26:760-777. 